8. Shaginyan, M. S. (1968). Joseph Myslivechek ("Resurrection from the Dead"). (Issue 450 The Life of Wonderful People). Moscow: Molodaya gvardiya [in Russian].

9. Shteynpress, B. S. \& Yampolskiy, I. M. (1966). Encyclopedic Musical Dictionary. Moscow: Sovetskaya entsiklopediya [in Russian].

\title{
תimepamypa
}

1. Арановский М. Музыка, мышление, жизнь. Статьи, интервью, воспоминания / ред.-сост. Н. А. Рыжкова. Москва: Государственный институт искусствознания, 2012. 440 с.

2. Дружинин В.Н.Психология общих способностей. Москва: Лантерна : Вита, 1995. 150 с.

3. Ломов Б. Ф., Сурков Е. Н. Антиципация в структуре деятельности. Москва: Наука, 1980. 280 с.

4. Мальцев С. О психологии музыкальной импровизации. Москва: Музыка, 1991. 88 с.

5. Муха А. И. Процесс композиторского творчества. Киев: Музична Україна, 1979. 271 с.

6. Петрушин В. Музыкальная психология: Учебное пособие для вузов. 2-е изд. Москва: Академический Проект; Трикста, 2008. 400 с.

7. Пономарев Я. А. Психология творческого мышления. Москва: Наука,1960. 352 с.

8. Шагинян М. С. Йозеф Мысливечек ("Воскрешение из мертвых"). Москва: Молодая гвардия, 1968. 339 с.: (Жизнь замечательных людей, вып. 450).

9. Штейнпресс Б.С., Ямпольский И. М. Энциклопедический музыкальный словарь. Москва: Советская энциклопедия, 1966. 632 с.

Стаття надійшла до редакції 15.11.2019 р. Прийнято до публікації 13.12.2019 р.

УДК 75.03 (477.85)"19-20"

\author{
Міщенко Ірина Іванівна \\ кандидат мистецтвознавства, доцент, \\ докторант Національної академії \\ керівних кадрів культури і мистецтв \\ ORCID 0000-0002-3525-5885 \\ irynart@ukr.net
}

\section{ЖИВОПИС АРТЕМА ПРИСЯЖНЮКА: ВІД ТЕМАТИЧНОЇ КАРТИНИ ДО АБСТРАКТНОЇ КОМПОЗИЦІї}

\begin{abstract}
Мета статті: мистецтвознавчий аналіз доробку Артема Присяжнюка, творчість якого є показовою 3 точки зору зміни стилістики в українському мистецтві кінця XX - початку XXI ст.. Методологією дослідження $є$ історичний, біографічний та системний підходи. Використаний також мистецтвознавчий аналіз, методи порівняння та узагальнення. Наукова новизна полягає у введенні в науковий обіг відомостей про сучасне буковинське мистецтво та творчість окремих художників, аналізі стилістичних змін у малярстві регіону. Висновки. Дослідження цієї теми дає змогу об'єктивно підійти до мистецтвознавчої оцінки поступу буковинського живопису кінця XX перших десятиліть XXI ст. загалом та спадщини окремих майстрів. У доробку Артема Присяжнюка (1947-2017) наявні твори монументального мистецтва, гобелени, скульптурні та живописні роботи. Дослідження творчості художника від кінця 1980-их до 2010-их рр. дозволяє відстежити зміни у його малярстві - поступовий перехід від тематичних картин, робіт публіцистичного характеру до абстрактних композицій. Значними чинниками впливу на формування живописної манери митця стали увага до композиційної структури робіт, характерна для львівської художньої школи, та професійне заняття гобеленом (А. Присяжнюк за освітою був художником текстилю). Останнє визначило особливо важливу роль фактури поверхні у малярських творах цього автора. Якщо у роботах кінця 1980-их - початку 1990-их рр. найчастіше зустрічалися публіцистичні мотиви, обумовлені соціально-політичною ситуацією в Україні і зверненням до неоднозначних і складних періодів в історії держави, то згодом найбільшим зацікавленням митця стане відображення емоційних станів та сприйняття сучасних подій через асоціації, відтворені співвідношенням колірних плям та ритмом ліній, грою різноманітних фактур тощо.
\end{abstract}

Ключові слова: Артем Присяжнюк, гобелен, живопис, Чернівці, тематична картина, абстрактне мистецтво.

Мищенко Ирина Ивановна, кандидат искусствоведения, доцент, докторант Национальной академии руководящих кадров культуры и искусств

Живопись Артема Присяжнюка: от тематической картины к абстрактной композиции

Цель статьи: искусствоведческий анализ наследия Артема Присяжнюка, творчество которого является показательным с точки зрения изменения стилистики в украинском искусстве конца XX - начала XXI века. Методологией исследования являются исторический, биографический и системный подходы. Использован также искусствоведческий анализ, методы сравнения и обобщения. Научная новизна заключается во введении в научный оборот сведений о современном буковинском искусстве и творчестве отдельных художников, анализе стилистических изменений в живописи региона. Выводы. Исследование этой темы позволяет объективно подойти к искусствоведческой оценке развития буковинской живописи конца XX - первыX десятилетий XXI в. в целом и наследия отдельных мастеров, в частности. Среди работ Артема Присяжнюка (1947-2017) есть произведения монументального искусства, гобелены, скульптурные и живописные работы. Исследование творчества художника с конца 1980-х до 2010-х гг. позволяет отследить изменения в его живописи - постепенный переход от

() Міщенко І. І., 2020 
тематических картин, работ публицистического характера к абстрактным композициям. Значительными фракторами влияния на формирование живописной манеры художника стали внимание к композиционной структуре работ, характерное для львовской художественной школы, и профессиональное занятие гобеленом (А. Присяжнюк по образованию был художником по текстилю). Последнее предопределило особенно важную роль фрактуры поверхности в живописных произведениях этого автора. Если в работах конца 1980-х - начала 1990-х гг. часто встречались публицистические мотивы, обусловленные социально-политической ситуацией в Украине и обращением к неоднозначным и сложным периодам в истории государства, то впоследствии наиболее значимым для художника станет отображение эмоциональных состояний и восприятия современных событий через ассоциации, воспроизведенные соотношением цветовых пятен и ритмом линий, игрой разнообразных фактур.

Ключевые слова: Артем Присяжнюк, гобелен, живопись, Черновцы, тематическая картина, абстрактное искусство.

Mishchenko Iryna, PhD of Arts, associate professor, doctoral candidate at the National Academy of Leading Cadres of Culture and Arts

Painting of Artem Prisyazhnyuk: from themed paintings to abstract compositions

Purpose of the article is to provide the artistic analysis of the works of Artem Prisyajnyuk, whose creativity is indicative of the changes of stylistics in the Ukrainian art of the late 20th - beginning of the 21st centuries. The methodology of this study is a historical, biographical and systematic approach; artistic analysis, methods of comparison and generalization were also used. Scientific novelty is in the introduction into the scientific circulation of information about contemporary Bukovynian art and creativity of individual artists, the analysis of stylistic changes in the painting of the region. Conclusions. The study of this topic makes it possible to objectively approach the scientific study of the progress of Bukovynian painting at the end of the 20th - the first decades of the 21st century in general as well as the heritage of individual masters. Artem Prysyazhnyuk's works (years of life 1947-2017) include works of monumental art, tapestries, sculptures, and paintings. The study of the artist's creativity from the late 1980s to the 2010 s allows us to track changes in his painting - a gradual transition from thematic paintings and works of journalistic nature to abstract compositions. Significant factors influencing the formation of the artist's painterly manner were attention to the compositional structure of the works, characteristic to the Lviv art school, and professional tapestry (A. Prysyazhnyuk was a textile artist by education). The latter identified the particularly important role of surface texture in the paintings of this author. The works of the late 1980s - early 1990s most frequently encountered journalistic motives due to the socio-political situation in Ukraine and the appeal to ambiguous and difficult periods in the history of the country. Later the greatest interest of the artist became the reflection of the emotional states and perception of modern events through associations reproduced by the ratio of color spots and the rhythm of lines, the play of various textures, etc.

Key words: Artem Prysyazhnyuk, tapestry, painting, Chernivtsi, thematic painting, abstract art.

Актуальність теми дослідження зумовлена тим, що образотворче мистецтво Північної Буковини середини XX - початку XXI ст. до сьогодні практично не було предметом вивчення науковцями. Незначна кількість публікацій, видрукуваних, переважно, у місцевих часописах, не дає змоги говорити про існування вичерпної й об'єктивної картини розвитку як буковинської образотворчості загалом, так i живопису окремих авторів. Зважаючи на це, вивчення доробку художників, котрі працювали протягом згаданого періоду, є актуальним з погляду всебічного висвітлення як розвитку регіонального малярства, так і історії українського мистецтва останніх десятиліть.

Аналіз досліджень і публікацій свідчить, що зазначена тема не знайшла належного відображення у науковій літературі та недостатньо висвітлена навіть у науково-популярних виданнях і дописах. Джерелами інформації з цього питання є проспекти, каталоги від кінця 1980-их до 2018 р., видані Чернівецькою організацією Спілки художників України і присвячені окремим виставкам, участь у яких брав А. Присяжнюк, статті у буковинських газетах та енциклопедичних виданнях $[1 ; 2 ; 3 ; 4 ; 6 ; 7 ; 8 ; 10]$. Останні, як і видана 1998 р. книжка «Митці Буковини» [9], містять біографічні дані про митця, не розкриваючи, проте, особливості стилістики його творів. Каталоги ж дають змогу ознайомитися з репродукціями тільки окремих робіт цього автора, не створюючи повноцінного уявлення про його живопис.

Найбільш повно на сьогодні творчість А. Присяжнюка розглянуто у статті І. Міщенко, вміщеній у збірнику «Хотинська звитяга» [5]. Проте, ця публікація не охоплює роботи останніх п'ятнадцяти років життя художника. Отже, не існує узагальнюючої праці, у якій повною мірою було б висвітлено малярський доробок одного з цікавих митців регіону кінця XX - початку XXI ст., що доводить необхідність вивчення цього питання.

Мета дослідження полягає в аналізі чинників, які вплинули на фоормування та стилістичні зміни у малярстві Артема Присяжнюка, оскільки його творчий шлях є показовим для розвитку буковинського живопису кінця XX - перших десятиліть XXI ст.. Наукова новизна розвідки зумовлена введенням у науковий обіг значної кількості творів художника, доробок якого досі недостатньо репрезентований у наукових та науково-популярних працях.

Виклад основного матеріалу. Артем (Артемій) Присяжнюк (1947-2017) навчався у Вижницькому училищі прикладного мистецтва на відділенні художнього конструювання промислових виробів 3 металів і пластмас (1967-1971), що зумовило згодом інтерес художника до скульптури (він був автором меморіальних дощок митрополитові $€$. Гакману, О. Ольжичу та ін. у Чернівцях). Після закінчення фракультету художнього текстилю Львівського державного інституту прикладного та декоративного мистецтва (1974-1979), де його вчителями були В. Монастирський, І. Гуторов, І. Боднар, мешкав у Чернівцях. Отримана освіта багато в чому визначила як галузі, в яких працював художник (гобелен, 
монументально-декоративне мистецтво, скульптура, станковий живопис), так і мистецькі уподобання цього автора.

Після закінчення Львівського інституту першою роботою А. Присяжнюка у Чернівцях став розпис у ресторані «Дністер» (1980). Згодом було виконано монументальний цикл «Мистецтво Київської Русі» у ресторані «Київ» (1983). Органічно вписані в обриси ніш, побудовані на зіставленні планів 3 різномасштабними зображеннями, ці роботи вирізняються дещо незвичним поєднанням епічності й проникливої лірики.

У той же період створено й урочисто-піднесену за звучанням мозаїку «Квітуй, Буковино!» (1982, у співавторстві з І. Віхренком), карбовані рельєфи для Будинку культури у Тарашанах Чернівецької обл. (1986), гобелен-завісу «Музика» для м. Первомайська на Миколаївщині (1990). Щоправда, попри значну кількість виконаних робіт, нездійсненними залишилися збережені тільки в ескізах десятки мозаїчних панно, розписів, вітражів та гобеленів. Артем Присяжнюк уже тоді виконує і нефігуративні композиції, створюючи, наприклад, незвичні за вирішенням вітражі для Будинку культури у Новоселиці Чернівецької обл. (1988).

Проте, найбільш послідовним став розвиток художника у гобелені. Присутнє в ранніх творах прагнення віднайти сучасне прочитання традиційних для народного килимарства Буковини символів згодом змінилося втіленням модернових мистецьких ідей у сповнених асоціацій композиціях тканих робіт. Серед перших творів - «Буковинська казка» (ескіз 1981 р.), в якій мотиви народного мистецтва переплелися з класичними літературними образами. До пізніших належать триптихи «Музика» (1988), «Полудень (Посвята батькам)» (1989), «Перетворення» (1989), «Осінь» (1992).

До середини 1980-их рр. належать і перші спроби художника виразити себе у станковому малярстві. Зацікавлення живописом збіглося в часі з руйнуванням звичних для соціалістичного реалізму, десятиліттями ідеологічних обмежень «освячених» художніх стереотипів. А. Присяжнюку вдалося оминути період зовнішньо-ефектних повторень, якими на той час наповнені були виставкові зали. Зміни у мистецтві України, зумовлені зламом соціальної формації, не лише спричинили переосмислення історичних фактів, а й сприяли засвоєнню розмаїття модерних мистецьких практик. Попри те, що характерною рисою живопису художника цього періоду була публіцистичність, в його роботах вона майже ніколи не набувала форм декларативної плакатності, оскільки він прагнув відтворити змістову ідею не тільки через застосування пізнаваних образів-символів, а й інтонацію, висловлену в колірних сполученнях.

Роботи кінця 1980-их - початку 1990-их рр. - часто драматичні, емоційно-чуттєві, нерідко просякнуті відчуттям болю, адже автор відгукувався на виклики часу, прагнув осмислити, пропустивши «крізь себе», складні події в історії України. Протягом лише кількох років у художника з'явиться низка творів про людське в людині, часом це будуть твори-докори, іноді - публіцистично-жорсткі, та частіше - зболено-сумні за звучанням. Вони поставатимуть як втілення спроб не лише висловити власні відчуття, а й віднайти в інших відгук на свій і спільний для багатьох біль. В них, крізь гіркоту й несподівану для робіт такого роду ніжність, лунав заклик до милосердя щодо тих, хто поруч. Такими були «Інтернат» (1989), «Пам'яті ненароджених» (1990), «Біля порога» (1990). Відгуком на масове захворювання дітей на алопецію стала робота «Чернівці. Серпень 88 року», в якій крізь вікно з вазоном, з якого осипалося листя, проглядали дахи спорожнілого міста.

Бурхливо-феєричний натюрморт «Свято Незалежності» (1991), в якому відбилося відчуття обретіння омріяної державності, виник поруч з відчуттям трагічної невідворотності подій в роботі «l радість, і печаль» (2000) та світлої печалі «Ангела-хранителя» (1992). Згадані твори вирізнялися чуттєвістю, проте колірне вирішення, побудоване на зіставленні близьких за тоном барв, підкреслювало стриманість емоцій («Тиша», 1991; «Червона рута», 1992).

Сповнені умовності, ці роботи, однак, зверталися до зображень, які асоціювалися з класичними візуальними або літературними образами. Витоки пластичного вирішення творів А. Присяжнюка згаданого періоду можна віднайти в іконописі Візантії, європейському мистецтві першої третини XX ст., що загалом було характерним для доробку значної кількості митців тогочасної України, котрі від початку 1960-их рр. прагнули наново відкрити, переосмислити та трансформувати культурну спадщину доби модернізму.

Спроби досягти більшої живописної свободи помітнішими були у натюрмортах художника, які надавали ширші можливості для експериментів. І спертися тут можна було не лише на класичні, визнані зразки Поля Сезанна, Джорджо Моранді, а й на праці значно ближчих за часом і сприйняттям світу Данила Довбошинського, Карла Звіринського, котрі викладали у Львівському інституті, Одарки Киселиці, персональна виставка якої у Чернівцях 1989 р. стала відкриттям живопису добірної вишуканості. Можливо, саме в подібних роботах відбувся перехід художника до умовності у зображенні реальних предметів, використання узагальнених обрисів, більшої декоративності та площинності елементів, що знову ж таки нагадувало сезаннівський підхід до потрактування речей. Натюрморти того часу побудовані на чіткості лінійних ритмів, пуристичній простоті й виразності контурів предметів. Живописна поверхня у таких творах найдовше залишалася пастозною, з підкреслено відчутними фактурами. Згодом емоції, що стали поштовхом до створення багатьох полотен, в яких думки не скуті зображеннями реальних об'єктів, відтворювалися через співвідношення колірних плям, їхню динамічну 
взаємодію, не замикаючись у пізнавані форми видимої реальності («Сон», 1990; «Створення», 1991).

Роботи кінця 1980-их - початку 1990-их рр. позначені тяжінням до монументальності, яка виразилася у лаконічності геометризованих мотивів, використанні великих площин локального кольору. Цікаво, що простір, вирішений за принципом побудови сцени театру, деяка жорсткість форм, вільні від зображень колірні площини, використання світлотіньових контрастів, сувора стриманість гами, а часом експресивна виразність різких поєднань барв, властиві живопису цього періоду, практично повністю відсутні у гобеленах художника того ж часу. Адже на початку 1990-их рр. його гобелени складніші за колірним вирішенням, вони побудовані на поєднанні різних за інтенсивністю тона та звучністю кольору плям з мальовничими відтінками.

У подальшому А. Присяжнюк рухатиметься в напрямку поступового вивільнення кольору від його замкненості у предметних формах, натомість більшу вагу матимуть колірні сполучення та фактури. У малярстві митця відчуватиметься і вплив значного досвіду роботи над гобеленами, для яких розмаїття фактур є одним з важливих засобів виразності. Власне, вже у цих роботах поступово вимальовуватимуться принципи вирішення, які у 2000-2010-их рр. визначать стилістичні риси нефігуративного живопису художника.

У роботах останніх років він вирвався за межі форми пізнаваної, аби створювати іншу реальність - чуттєву, з відкритим простором чистих кольорів та фрізичною відчутністю фрактур («Без назви», 2016). I саме тоді полотна набули рівноваги і заразом - здатності відтворити умиротворення, ніжність, втілені у перетіканні відтінків кольорів. В цих творах відчутний і досвід праці в художньому ткацтві та скульптурі, що виявився в увазі до пропорцій і ритмів, у вільному оперуванні масами кольорів, врешті - в лаконічності образної мови. Подекуди свої композиції він і вирішує як гобелен або панно, максимально узагальнюючи обриси, позбуваючись описовості й публіцистичності, притаманної творам кінця 1980-их - 1990-их років. Художник уникає гострих кутастих форм навіть у роботах, де існують, здавалось би, хаотичні нашарування площин. Проте і в них є відчуття нерозривної пов'язаності елементів, а їхня взаємодія відтворює відчуття енергії, що народжує рух. Нерідко активні дрібномасштабні діагональні елементи, що перетинаються, нашаровуються один на другий, з'являються на спокійноурочистих великих площинах, розбиваючи їхню впорядкованість і статичність, привносячи акцент, який миттєво змінює сприйняття, активізуючи його.

Подекуди чітко окреслені площини чистого кольору з гладкою поверхнею межують 3 експресивними, активними фактурами сусідніх форм. Проте в більшості живописних полотен відсутній дух протиборства елементів, мас, фрактур, адже всі вони підкреслюють один одного, роблячи емоційно виразнішим настрій роботи, формуючи раціональне й чуттєве сприйняття останньої.

Роботи 2005-2016 рр., попри те, що художник продовжує створювати портрети (зокрема, портрети членів родини) демонструють перехід від тематичних та публіцистичних творів або картинвідбиттів до абстрактних композицій, в яких автор прагне вирішувати завдання фрормального характеру, оперуючи не пізнаваними формами реального світу, а підкреслюючи самодостатність живописних елементів. Він звертається до набутків мистецтва модернізму, трансформуючи їх, пропонуючи відмінне бачення поступу мистецтва нефігуративу.

Висновки. Докладний аналіз доробку Артема Присяжнюка, передовсім, живопису митця 19802016 рр., дозволяє відстежити зміни у його творчості, які засвідчують поступовий перехід до нефігуративних композицій, в яких найбільш вагомими елементами виступають колір та фрактура живописної поверхні.

Останнє було зумовлено не тільки зверненням художника до переосмислення мистецьких практик XX-XXI ст., а й впливом львівської художньої школи, для якої характерною була увага до композиційної структури робіт, та значним досвідом роботи над створенням гобеленів.

Якщо у роботах кінця 1980-их - початку 1990-их рр. найчастіше зустрічалися публіцистичні мотиви, обумовлені соціально-політичною ситуацією в Україні і зверненням до складних періодів в історії держави, то згодом митець прагнутиме відтворювати емоційний стан та сприйняття сучасних подій через асоціації, співвідношення колірних плям, розмаїття фрактур.

\section{תimepamypa}

1. 1 триєнале «Український фолькмодерн 2009». Чернівці: ТОВ «Друк Арт», 2009. С. 22, 32.

2. ART-AКT. Друга всеукраїнська трієнале абстрактного мистецтва. Чернівці: ДрукАрт, 2013. С. 28.

3. АRT-АКТ. Перша всеукраїнська триєнале абстрактного мистецтва. Чернівці: ДрукАрт, 2010. С. 14, 38.

4. ART-АКT. Третя всеукраїнська трієнале абстрактного мистецтва. Чернівці: ДрукАрт, 2016. С. 3.

5. Міщенко І. Артем Присяжнюк. Хотинська звитяга. Чернівці: Золоті литаври, 2002. С.134-137.

6. Всеукраїнська виставка образотворчого мистецтва, присвячена 70-літньому ювілею Івана Миколайчука. Чернівці. Б. р. С. 36, 39.

7. Всеукраїнська художня виставка «Мальовнича Україна». Чернівці, 2009. С. 8, 20.

8. Мистецтво Буковини : каталог. Чернівці, 2004. С. 42.

9. Митці Буковини: Енцикл. довід. / Авт.-упоряд. Т. Дугаєва, І. Міщенко. Т.1. Чернівці : Золоті литаври, 1998. C. 90

10. Перша всеукраїнська триєнале «не-актуального» мистецтва «РREЧИСТА». Чернівці: ТОВ «ДрукАрт», 2011. C. 20,36 


\begin{abstract}
References
1. 1 try yenale "Ukrainian Folkmodern 2009" (2009). Chernivci: TOV «Druk Art», 22, 32 [in Ukrainian].

2. ART-AKT. Second All-Ukrainian Triennial of Abstract Art. (2013). Chernivci: DrukArt, 28 [in Ukrainian].

3. ART-AKT. The first all-Ukrainian triennial of abstract art. (2010). Chernivci: DrukArt, 14, 38 [in Ukrainian].

4. ART-AKT. Third All-Ukrainian Triennial of Abstract Art. (2016). Chernivci: DrukArt, 3 [in Ukrainian].

5. Mishchenko, I. (2002). Artem Prysjazhnjuk. Khotyn Wanderer. Chernivci: Zoloti lytavry, 134-137 [in Ukraini-

an].

6. All-Ukrainian Exhibition of Fine Arts, dedicated to the 70th anniversary of Ivan Mykolaichuk. (n.d.). Chernivci, 36, 39 [in Ukrainian].

7. All-Ukrainian Art Exhibition "Picturesque Ukraine" (2009). Chernivci, 8, 20 [in Ukrainian].

8. Bukovina Art: Catalog. (2004). Chernivci [in Ukrainian].

an].

9. Bukovina Artists. Dughajeva, T. \& Mishchenko, I. (Eds.). (1998). Vol. 1. Chernivci: Zoloti litavry [in UkrainiUkrainian].

10. The first all-Ukrainian triennial of "non-relevant" art "PURE." (2011). Chernivci: TOV «DrukArt», 20, 36 [in
\end{abstract}

Стаття надійшла до редакції 04.11.2019 p. Прийнято до публікації 29.11.2019 р.

УДК $7.048: 7.035 .93$

\author{
Оборська Світлана Валентинівна \\ кандидат мистецтвознавства, доцент \\ Київського національного університету \\ культури і мистецтв \\ ORCID 0000-0003-3148-6325 \\ lychia0801@gmail.com
}

\title{
СПЕЦИФІКА ОРНАМЕНТАЛЬНОЇ СТИЛІЗАЦІЇ ДЕКОРУ СТИЛЮ МОДЕРН
}

\begin{abstract}
Мета статті - проаналізувати символічне значення зооморфних, фрлороморфних, орнітоморфних та інсектоморфних мотивів декору стилю модерн, виявити специфіку орнаментальної стилізації. Методи дослідження. У статті застосовано системно-історичний метод дослідження (для осмислення специфіки орнаментальної стилізації в розвитку), системного аналізу (орнамент декору стилю модерн розглядається як частина знакової системи), а також методи класифікації та порівняльного аналізу (використано при вивченні візуального матеріалу). Наукова новизна. Проаналізовано орнаментальні мотиви декору стилю модерн; визначено передумови виникнення та розвитку флороморфного і геометричного орнаменту, принципи стилізації орнаментальних образів та їх символіку. Висновки. Новаторство образів превалювало в творчості художників модерністів, які розробили новий колорит, форму, фактуру, а головне - унікальний орнамент, що став найхарактернішою ознакою стилю. Флороморфні, зооморфні, орнітоморфні, інсектоморфні, антропоморфні та геометричні мотиви, що вирізнялися відносною образністю та алегорією стають провідною тематикою орнаментики модерну, осмислюючись як система символів, що передає світ нереальний, дивовижний та прекрасний.
\end{abstract}

Ключові слова: модерн, стилізація, орнаментика, флороморфні та зооморфні мотиви, символіка, декор.

Оборская Светлана Валентиновна, кандидат искусствоведения, доцент Киевского национального университета культуры и искусств

Специфика орнаментальной стилизации декора стиля модерн

Цель статьи - проанализировать символическое значение зооморфных, флороморфных, орнитоморфных и инсектоморфных мотивов декора стиля модерн, выявить специфику орнаментальной стилизации. Методы исследования. В статье применены системно-исторический метод исследования (для осмысления специфики орнаментальной стилизации в развитии), системного анализа (орнамент декора стиля модерн рассматривается как часть знаковой системы), а также методы классификации и сравнительного анализа (использовано при изучении визуального материала). Научная новизна. Проанализированы орнаментальные мотивы декора стиля модерн; определены предпосылки возникновения и развития фрлороморфного и геометрического орнамента, принципы стилизации орнаментальных образов и их символика. Выводы. Новаторство образов превалировало в творчестве художников модернистов, которые разработали новый колорит, форму, фрактуру, а главное - уникальный орнамент, который стал характерным признаком стиля. Флороморфные, зооморфные, орнитоморфные, инсектоморфные, антропоморфные и геометрические мотивы, которые отличались относительной образностью и аллегорией, становятся ведущей темой орнаментики модерна, осмысливаясь как система символов, что передает мир нереальный, удивительный и прекрасный.

Ключевые слова: модерн, стилизация, орнаментика, флороморфные и зооморфные мотивы, символика, декор.

Obskaya Svetlana, Candidate of Arts, Associate Professor Kyiv National Culture and Arts University The specifics of the ornamental stylization of Art Nouveau decor

(C) Оборська С. В., 2020 